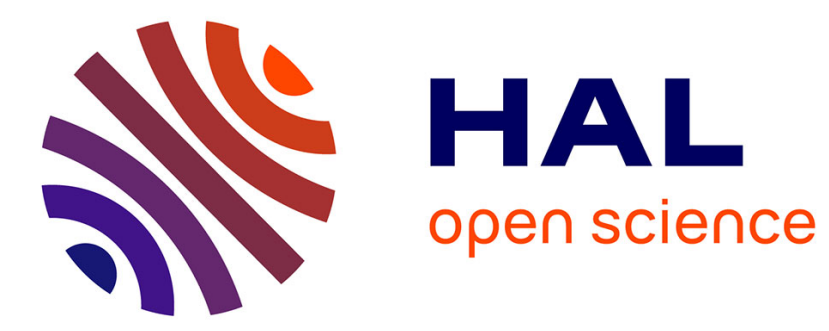

\title{
GENOMIC, PROTEOMIC AND LACTATION
}

Eric Chanat, F. Leprovost, M. Ollivier-Bousquet

\section{To cite this version:}

Eric Chanat, F. Leprovost, M. Ollivier-Bousquet. GENOMIC, PROTEOMIC AND LACTATION.

Reproduction Nutrition Development, 2003, 43 (5), pp.437-437. 10.1051/rnd:2003038 . hal-00900519

\section{HAL Id: hal-00900519 \\ https://hal.science/hal-00900519}

Submitted on 1 Jan 2003

HAL is a multi-disciplinary open access archive for the deposit and dissemination of scientific research documents, whether they are published or not. The documents may come from teaching and research institutions in France or abroad, or from public or private research centers.
L'archive ouverte pluridisciplinaire HAL, est destinée au dépôt et à la diffusion de documents scientifiques de niveau recherche, publiés ou non, émanant des établissements d'enseignement et de recherche français ou étrangers, des laboratoires publics ou privés. 


\title{
INRA-Meeting
}

\section{GENOMIC, PROTEOMIC AND LACTATION}

\author{
INRA Research Centre of Jouy-en-Josas, France \\ 12 November 2002
}

Hereafter in this issue of "Reproduction, Nutrition, Development" are some review articles of the presentations made at the second meeting* of an INRA network bringing together teams from different Departments of the Institute working on the mammary gland and milk.

The meeting was dedicated to "omic" approaches of mammary gland biology and to some topics related to the physiopathology of the tissue. The programme encompassed theoretical aspects of the methods used in genomics and in proteomics, as well as several applications of these technologies to the elucidation of the functioning of the mammary tissue and characterisation of milk proteins. The last session featured presentations on both the immunophysiology and the physiopathology of the mammary gland.

We thank all those contributors and participants who, in our view, made the meeting a success. We are also grateful to the referees for their cooperation and to all concerned by the editorial process.

\section{E. Chanat, F. LeProvost, M. Ollivier-Bousquet \\ E-mail address: chanat@jouy.inra.fr}

\footnotetext{
* The meeting was supported by INRA, "Département de Physiologie Animale".
} 